\title{
Pharmacokinetics of Fluoxetine in Rhesus Macaques following Multiple Routes of Administration
}

\author{
E.K. Sawyer ${ }^{\mathrm{a}}$ L.L. Howell ${ }^{\mathrm{b}, \mathrm{c}}$ \\ ${ }^{a}$ Neuroscience Program, ${ }^{b}$ Division of Neuropharmacology and Neurologic Disease, Yerkes National Primate \\ Research Center, and 'Department of Psychiatry and Behavioral Sciences, Emory University, Atlanta, Ga., USA
}

\section{Key Words}

Fluoxetine $\cdot$ Norfluoxetine $\cdot$ Nonhuman primate $\cdot$

Pharmacokinetics $\cdot$ Selective serotonin reuptake inhibitors

\begin{abstract}
Background/Aims: Fluoxetine (Prozac) is a selective serotonin reuptake inhibitor currently used to treat depression and mood disorders. It has been widely studied clinically and preclinically, yet there is limited knowledge of its pharmacokinetics in nonhuman primates. Methods: The present study characterized the pharmacokinetics of fluoxetine and its active metabolite norfluoxetine in rhesus macaques following both acute $(1,3,5.6$ and $10 \mathrm{mg} / \mathrm{kg}$ ) and chronic doses (5.6 and $10 \mathrm{mg} / \mathrm{kg} /$ day) via different routes of administration (intravenous, subcutaneous, intramuscular, and oral). Blood samples were collected at multiple time points following administration and analyzed using mass spectrometry. Results: Fluoxetine had a half-life of 11-16 h and norfluoxetine had a half-life of 21-29 h. Potentially functionally significant serum concentrations of norfluoxetine were present at $24 \mathrm{~h}$ even after a single administration of fluoxetine. Similar to observations in humans under steady state conditions, norfluoxetine accounted for the greater percentage of active drug in the blood stream. Conclusion: A daily dose of $10 \mathrm{mg} / \mathrm{kg}$ administered orally maintained serum concentrations in the human
\end{abstract}

clinical range over the course of 6 weeks. Given the long halflives of fluoxetine and norfluoxetine observed in this study, precautions should be taken when designing preclinical studies to prevent accumulation of drug serum concentrations.

Copyright $\odot 2011$ S. Karger AG, Basel

\section{Introduction}

Fluoxetine is a selective serotonin reuptake inhibitor (SSRI) which is currently approved for treatment of depression and mood disorders. It is one of the oldest and most frequently prescribed SSRIs [1]. Fluoxetine binds to the serotonin transporter (SERT), blocking reuptake of the neurotransmitter into the presynaptic cell, which results in acute increases in levels of extracellular serotonin $[1,2]$. However, the onset of therapeutic effects is delayed for 3-4 weeks, suggesting that there may be neurobiological adaptations involved in its action $[1,3,4]$.

Fluoxetine is metabolized by cytochrome $\mathrm{P} 450$ enzymes, with the CYP2CP and CYP2D6 enzymes playing a large role. The major metabolite is norfluoxetine, which is biologically active with equal affinity for SERT [4-6]. Unlike the metabolites of most SSRIs, norfluoxetine contributes to the inhibition of serotonin reuptake in a functionally significant manner [6, 7]. In humans, fluoxetine

\section{KARGER}

Fax +4161306 1234 E-Mail karger@karger.ch www.karger.com
(C) 2011 S. Karger AG, Basel 0031-7012/11/0882-0044\$38.00/0

Accessible online at:

www.karger.com/pha
Leonard L. Howell, $\mathrm{PhD}$

Yerkes National Primate Research Center, Emory University

954 Gatewood Rd.

Atlanta, GA 30329 (USA)

Tel. +1 404727 7786,E-Mail lhowell@emory.edu 
has a half-life of 1-4 days while norfluoxetine has a longer half-life of 7-15 days [1, 4-6]. Furthermore, fluoxetine and norfluoxetine inhibit their own metabolism through interactions with the cytochrome P450 liver enzymes, particularly the CYP2D6 $[4,6]$. Thus, cumulative dosing, as is frequently used clinically, results in different blood concentrations and pharmacokinetics than acute dosing [5]. There is no clear serum concentration-therapeutic effect relationship reported for fluoxetine $[5,6,8]$, but serum concentrations from the human clinical setting are generally reported to be between 200 and $1,000 \mathrm{ng} / \mathrm{ml}$, including norfluoxetine [6,9-12].

The distinctive pharmacokinetics of fluoxetine may contribute to its clinical profile, as may the action of norfluoxetine. Therefore, it is important to take this information into consideration when designing and performing preclinical or animal studies using fluoxetine. However, very little information exists on the pharmacokinetics of fluoxetine in species commonly used for preclinical studies, particularly nonhuman primates. It has been reported that chronic administration of fluoxetine can achieve serum concentrations comparable to human clinical concentrations in rhesus macaques [13], yet there is no information available regarding the sustainability of these concentrations or the pharmacokinetics. Since pharmacokinetics may differ among species, we sought to characterize the pharmacokinetics of fluoxetine and norfluoxetine in nonhuman primates, and develop a clinically relevant dosing method for use in preclinical studies.

\section{Methods}

\section{Subjects}

Adult female rhesus macaques (Macaca mulatta) between 7 and $9 \mathrm{~kg}$ served as subjects. Animals were singly housed within a primate colony and fed Purina monkey chow (Ralston Purina, St. Louis, Mo., USA), fruits, and vegetables. Water was continually available. All procedures and studies strictly followed the National Institutes of Health Guide for the Care and Use of Laboratory Animals (Publication No. 85-23, revised 1985) and were approved by the Institutional Animal Care and Use Committee of Emory University.

\section{Acute Studies}

Female rhesus macaques ( $\mathrm{n}=4 ; 7-9 \mathrm{~kg}$ ) served as subjects. Animals were seated comfortably in Primate Products primate chairs for the duration of blood sample collection. Each animal was prepared by placing a temporary intravenous catheter into the saphenous vein (BD Saf-T-Intima Closed Catheter System; BD, Franklin Lakes, N.J., USA). Fluoxetine $\mathrm{HCl}$ was purchased from Spectrum Chemicals and Laboratory Products (N.J., USA) and dissolved in sterile water at a concentration of $7 \mathrm{mg} / \mathrm{ml}$. The drug was administered either i.m. (1, 3, 5.6 and $10 \mathrm{mg} / \mathrm{kg})$ or i.v. $(3 \mathrm{mg} / \mathrm{kg})$ and blood samples were collected through the catheter at 5, 15, 30, 60 and $120 \mathrm{~min}$ after injection. The animals were then returned to their home cages. For all doses except $10 \mathrm{mg} /$ $\mathrm{kg}$, animals were re-chaired and samples collected at 8 and $12 \mathrm{~h}$ post-injection, and again at $24 \mathrm{~h}$. Two animals were used per dose.

\section{Chronic Studies}

Female rhesus macaques ( $\mathrm{n}=7 ; 7-9 \mathrm{~kg}$ ) served as subjects. Fluoxetine $\mathrm{HCl}(5.6,10 \mathrm{mg} / \mathrm{kg})$ was administered once daily in the cage for 7 (5.6 mg/kg s.c. or p.o., $\mathrm{n}=2)$ or 42 days $(10 \mathrm{mg} / \mathrm{kg}$ p.o., $\mathrm{n}=5$ ). For subcutaneous injection, fluoxetine $\mathrm{HCl}$ was dissolved in sterile water at $7 \mathrm{mg} / \mathrm{ml}$ concentration. For oral administration, fluoxetine $\mathrm{HCl}$ was weighed and mixed with peanut butter or other palatable foods and spread on a piece of bread. Compliance was assessed via visual inspection of the animal's cage $1-2 \mathrm{~h}$ after the medicated treat had been given. Blood draws occurred once daily before drug administration for the 6-day administration and continued for a 6-day follow-up after ceasing drug administration. For the 42-day administration, blood draws occurred once weekly before daily drug administration.

\section{Sample Analysis}

Following collection, blood was centrifuged at 3,000 $g$ for 20 min. The serum was then collected and frozen for later analysis. Samples were analyzed using mass spectrometry and quantified against both internal standards and separate standard curves [14].

\section{Half-Life Determination}

The following formulae were used to calculate half-life:

$$
\begin{aligned}
& \mathrm{k}_{\text {elimination }}=\left(\ln \mathrm{C}_{2}-\ln \mathrm{C}_{1}\right) /\left(\mathrm{t}_{2}-\mathrm{t}_{1}\right) \\
& \mathrm{t}_{1 / 2}=0.693 / \mathrm{k}_{\text {elimination }}
\end{aligned}
$$

where $\mathrm{C}$ is concentration and $\mathrm{t}$ is time. Half-lives for fluoxetine and norfluoxetine were determined separately. For calculations for fluoxetine, $t_{1}$ was $24 \mathrm{~h}$ following the final administration of fluoxetine, and $t_{2}$ was $96 \mathrm{~h}$ after final administration. For norfluoxetine, $t_{1}$ was the time point at which fluoxetine concentrations were less than $5 \mathrm{ng} / \mathrm{ml}$ to ensure that metabolism of fluoxetine to norfluoxetine would no longer be significantly contributing to its concentration. $t_{2}$ was $48 \mathrm{~h}$ after $t_{1}$. Calculations were performed in Excel. Student's t test was used to compare half-lives for fluoxetine and norfluoxetine and was calculated using GraphPad (GraphPad Prism version 5.01 for Windows, GraphPad Software, San Diego, Calif., USA, www.graphpad.com).

\section{Results}

\section{Acute Fluoxetine Administration}

$1.0,3.0,5.6$, and $10 \mathrm{mg} / \mathrm{kg}$ fluoxetine all resulted in detectable serum concentrations of fluoxetine (fig. 1). Peak fluoxetine concentrations were achieved at $15 \mathrm{~min}$ (31 ng/ml), $30 \mathrm{~min}(70 \mathrm{ng} / \mathrm{ml}), 60 \mathrm{~min}(165 \mathrm{ng} / \mathrm{ml})$ and between 30 and $60 \mathrm{~min}(785 \mathrm{ng} / \mathrm{ml})$, respectively (fig. 1). Norfluoxetine first appeared at $120 \mathrm{~min}$ and was still 

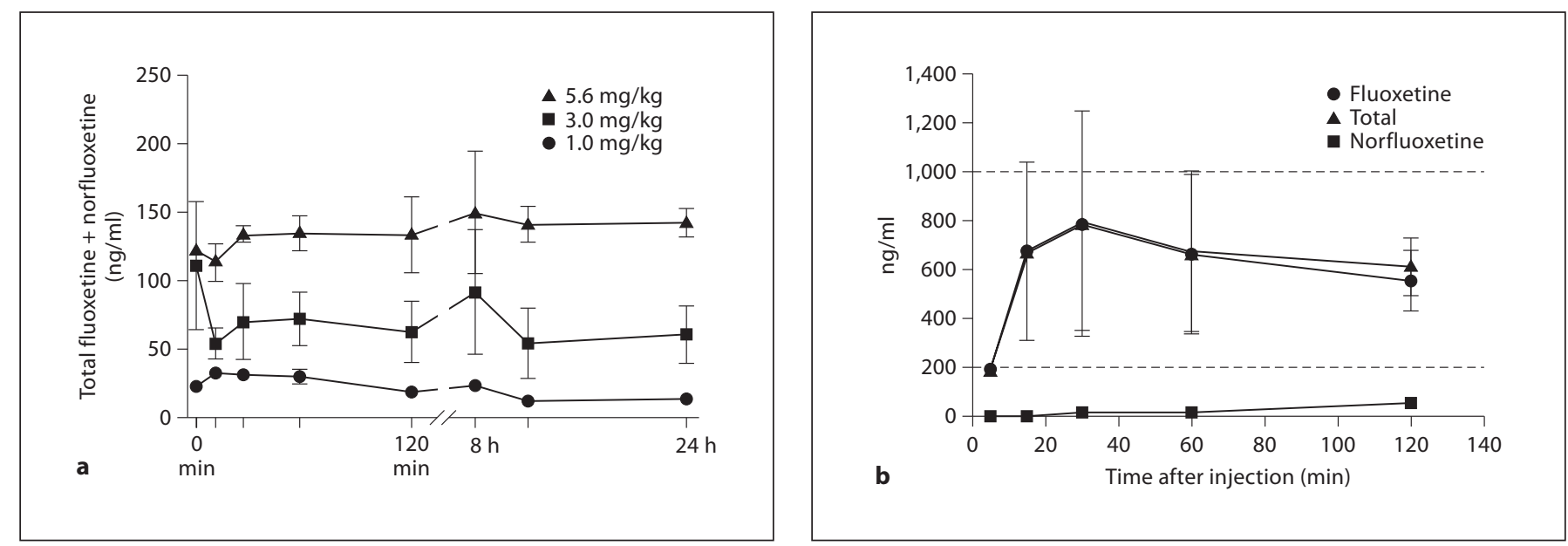

Fig. 1. Serum concentrations of total fluoxetine, fluoxetine, and norfluoxetine, following acute i.m. administration $(\mathrm{n}=2)$. a Total fluoxetine serum concentrations following administration of $1.0,3.0$ and $5.6 \mathrm{mg} / \mathrm{kg}$ fluoxetine are dose dependent and relatively stable, with significant active drug remaining $24 \mathrm{~h}$ after a single i.m. injection. b Fluoxetine, norfluoxetine, and total drug concentration following administration of $10.0 \mathrm{mg} / \mathrm{kg}$. Fluoxetine levels rapidly rise and reach the human clinical range; norfluoxetine levels do not significantly contribute during the first $120 \mathrm{~min}$ following injection. Dashed lines indicate the human clinical range.

present at the 24-hour time point for all doses $(14,61$, $142.8 \mathrm{ng} / \mathrm{ml}$, respectively; not evaluated for $10 \mathrm{mg} / \mathrm{kg}$ dose), forming the majority of active drug concentration at that time point (fig. 2).

Intravenous administration of $3.0 \mathrm{mg} / \mathrm{kg}$ resulted in a much higher $(11,913 \mathrm{ng} / \mathrm{ml})$ peak serum concentration than intramuscularly $(70 \mathrm{ng} / \mathrm{ml})$. The concentration peaked $15 \mathrm{~min}$ post-injection and then rapidly declined. Norfluoxetine had a comparatively small contribution to overall drug concentrations when administered i.v., reaching levels $<20 \mathrm{ng} / \mathrm{ml}$ up to $120 \mathrm{~min}$, and peaking at $108 \mathrm{ng} / \mathrm{ml}$ at $8 \mathrm{~h}$ after injection (data not shown). At $24 \mathrm{~h}$, a combined concentration of $50.6 \mathrm{ng} / \mathrm{ml}$ remained.

\section{Chronic Fluoxetine Administration}

Oral administration of $5.6 \mathrm{mg} / \mathrm{kg}$ resulted in lower serum concentrations (fluoxetine: $43.5 \mathrm{ng} / \mathrm{ml}$; norfluoxetine: $193.6 \mathrm{ng} / \mathrm{ml}$ ) as compared to subcutaneous administration (fluoxetine: $328.7 \mathrm{ng} / \mathrm{ml}$; norfluoxetine: 404.1 $\mathrm{ng} / \mathrm{ml}$ ) (fig. 3). The half-lives of both fluoxetine and norfluoxetine were significantly longer following subcutaneous administration as compared to oral administration: $16.16 \pm 2.56$ vs. $11.89 \pm 5.06 \mathrm{~h}$ for fluoxetine $(\mathrm{t}=3.01$; $\mathrm{p}<0.01)$ and $29.72 \pm 2.56$ vs. $21.29 \pm 0.08 \mathrm{~h}$ for norfluoxetine $(\mathrm{t}=4.66 ; \mathrm{p}<0.05)$, respectively (table 1$)$.

Daily oral administration of $10 \mathrm{mg} / \mathrm{kg}$ fluoxetine resulted in a stable serum concentration in the range

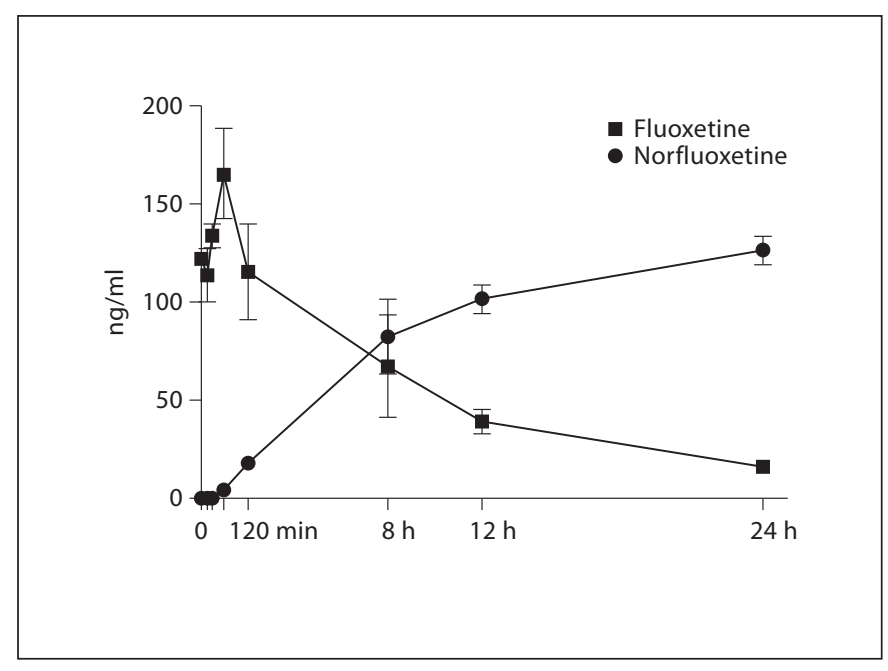

Fig. 2. Serum concentrations of fluoxetine and norfluoxetine following an acute $5.6 \mathrm{mg} / \mathrm{kg}$ i.m. injection of fluoxetine $(\mathrm{n}=2)$. As concentrations of fluoxetine fall, concentrations of norfluoxetine rise, resulting in a fairly consistent concentration of active drug in the blood.

of $250-450 \mathrm{ng} / \mathrm{ml}$ total fluoxetine + norfluoxetine and cleared in approximately 1 week ( $\leq 10 \mathrm{ng} / \mathrm{ml}$ ) (fig. 4). During chronic administration, norfluoxetine accounted for $70-80 \%$ of total active drug concentration. 


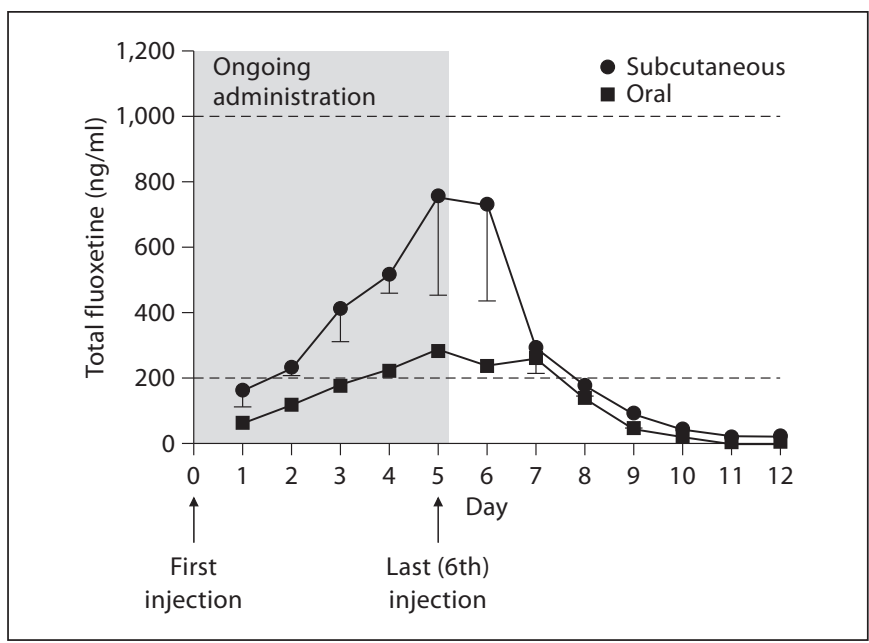

Fig. 3. Serum concentrations during and after 6-day administration of $5.6 \mathrm{mg} / \mathrm{kg}$ fluoxetine $\mathrm{HCl}$ s.c. or p.o. Concentrations steadily rise during administration and decline following cessation of treatment. Subcutaneous administration results in significantly higher serum concentrations. Both methods result in steady-state concentrations in the clinical range for humans. Dashed lines indicate the human clinical range.

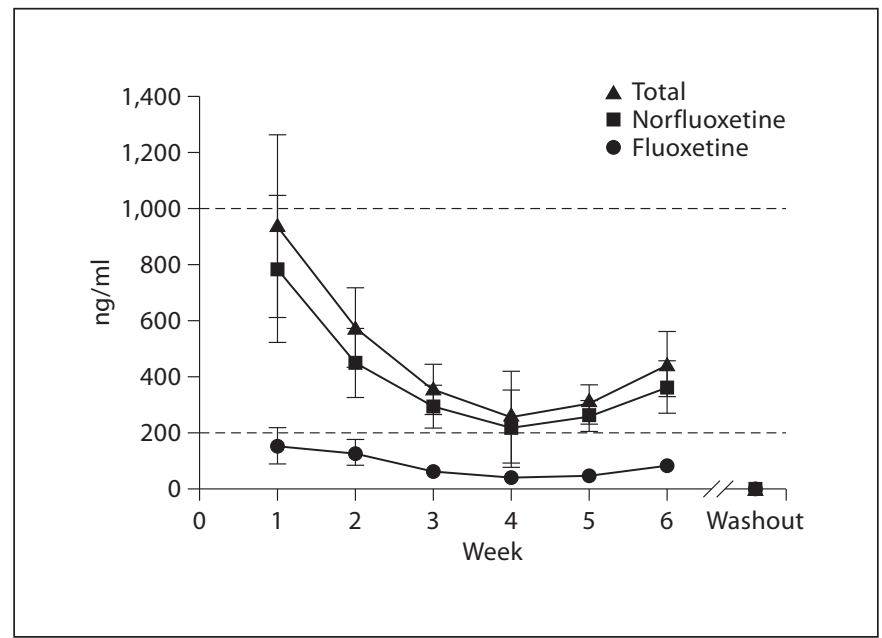

Fig. 4. Serum concentrations during 6-week chronic fluoxetine administration $(10 \mathrm{mg} / \mathrm{kg}$ p.o.; $\mathrm{n}=5)$. Serum concentrations are stable between weeks 3 and 6 and are maintained within the human clinical range for the duration of administration. Washout measurements were taken 1 week after the cessation of treatment. Dashed lines indicate the human clinical range.

Table 1. Comparative pharmacokinetics of fluoxetine and norfluoxetine between species

\begin{tabular}{|c|c|c|c|c|c|c|c|c|}
\hline \multirow[t]{2}{*}{ Species } & \multirow[t]{2}{*}{ Dose } & \multirow{2}{*}{$\begin{array}{l}\text { Route of } \\
\text { administration }\end{array}$} & \multicolumn{2}{|c|}{ Plasma levels, ng/ml } & \multicolumn{2}{|c|}{ Half-life, $\mathrm{h}$} & \multirow{2}{*}{$\begin{array}{l}\text { Fluoxetine:nor- } \\
\text { fluoxetine ratio }\end{array}$} & \multirow{2}{*}{$\begin{array}{l}\text { Refer- } \\
\text { ence }\end{array}$} \\
\hline & & & fluoxetine & norfluoxetine & fluoxetine & norfluoxetine & & \\
\hline \multirow[t]{2}{*}{ Mice } & $5 \mathrm{mg} / \mathrm{kg} /$ day & \multirow[t]{2}{*}{ intraperitoneal } & 729 & 847 & NR & NR & $0.86^{\mathrm{a}}$ & \multirow[t]{2}{*}{16} \\
\hline & $10 \mathrm{mg} / \mathrm{kg} /$ day & & $1,835.5$ & $1,516.5$ & NR & NR & $1.21^{\mathrm{a}}$ & \\
\hline \multirow[t]{2}{*}{ Rats } & $3 \mathrm{mg} / \mathrm{kg}$ & \multirow[t]{2}{*}{ subcutaneous } & NR & NR & 2.08 & 6.51 & $\mathrm{NC}$ & \multirow[t]{2}{*}{7} \\
\hline & $10 \mathrm{mg} / \mathrm{kg}$ & & NR & NR & 2.71 & 11.8 & $\mathrm{NC}$ & \\
\hline \multirow{3}{*}{$\begin{array}{l}\text { Nonhuman } \\
\text { primate }\end{array}$} & $5.6 \mathrm{mg} / \mathrm{kg} /$ day & oral & 63.9 & 193.6 & $11.89^{* *}$ & $21.29^{*}$ & 0.33 & \multirow{3}{*}{$\begin{array}{l}\text { present } \\
\text { study }\end{array}$} \\
\hline & $5.6 \mathrm{mg} / \mathrm{kg} /$ day & subcutaneous & 328.7 & 404.1 & 16.16 & 29.72 & 0.81 & \\
\hline & $10 \mathrm{mg} / \mathrm{kg} /$ day & oral & $41-83$ & $215-361$ & NC & $\mathrm{NC}$ & 0.23 & \\
\hline \multirow[t]{2}{*}{ Human } & $20 \mathrm{mg} /$ day & \multirow[t]{2}{*}{ oral } & $\begin{array}{l}73.62^{\mathrm{b}}, 98 \\
80,89-100\end{array}$ & $\begin{array}{l}108.39^{\mathrm{b}}, 127 \\
126,114-200\end{array}$ & \multirow[t]{2}{*}{ 1-4 days } & 7-14 days & $0.68^{\mathrm{b}}$ & \multirow[t]{2}{*}{$\begin{array}{l}1,4-6 \\
12,15\end{array}$} \\
\hline & $40 \mathrm{mg} /$ day & & $172.29^{\mathrm{b}}, 195$ & $168.93^{b}, 221$ & & & $1.02^{\mathrm{b}}$ & \\
\hline
\end{tabular}

Serum concentrations are reported from repeated dosing measures (minimum of 6 days).

${ }^{*} \mathrm{p}<0.05$ with respect to subcutaneous route of administration in nonhuman primates; ${ }^{* *} \mathrm{p}<0.01$.

${ }^{a}$ Calculated from plasma concentrations reported in table 1 in Hodes et al. [16]; ${ }^{\text {b }}$ calculated from data reported in table 3 in Reis et al. [12]. NR = Not reported; $\mathrm{NC}=$ insufficient data, not calculated.

\section{Discussion}

The present study characterizes the pharmacokinetics of fluoxetine in rhesus macaques, a species frequently used for preclinical studies, following both acute and chronic administration. To achieve serum concentrations comparable to the human clinical range, it was necessary to administer higher doses and to do so chronically, as expected from a previously published study by Fontenot et al. [13]. This is the first study to report the half-lives of 
fluoxetine and its active metabolite norfluoxetine in rhesus macaques, which were shorter than in humans. However, at higher doses, even a single administration could result in functionally significant levels $24 \mathrm{~h}$ later.

\section{Half-Life}

Fluoxetine has a reported half-life of 1-4 days in humans while norfluoxetine has a half-life of 7-15 days [1, $4-6,15]$. The pharmacokinetics of fluoxetine have also been described in mice [16] and rats [7] (table 1), but have not been comprehensively described in nonhuman primates. In the present study, chronic administration of 5.6 $\mathrm{mg} / \mathrm{kg}$ fluoxetine orally or subcutaneously resulted in significantly different half-lives for both fluoxetine and norfluoxetine. Since both fluoxetine and norfluoxetine inhibit CYP450 enzymes, which are involved in their metabolism [4-6], this difference in half-life is likely due to the difference in serum concentrations achieved by each mode of administration; the higher concentrations associated with subcutaneous administration resulted in longer half-lives, which is in concordance with previous reports of nonlinear pharmacokinetic parameters in humans [4-6] and in rats [7]. Our observed half-lives for fluoxetine and norfluoxetine are greater than that reported in rats [7] but still considerably less than that reported in humans $[1,5,6,15]$ (table 1$)$. As in rats, a single administration resulted in steady levels of active drug maintained through $24 \mathrm{~h}$ [7]. It is especially important to be aware of the possibility of functionally significant serum concentrations of drug remaining present past $24 \mathrm{~h}$ when designing preclinical studies with fluoxetine.

\section{Fluoxetine:Norfluoxetine Ratio}

Under steady state in humans norfluoxetine exceeds fluoxetine [5]; this finding was also observed in mice [16] and monkeys [13] and now has been replicated in the present study (table 1). Unlike the data reported by Fontenot et al. [13], fluoxetine:norfluoxetine ratios were not substantially higher in monkeys than those reported in humans [9-12]. Norfluoxetine is as potent a reuptake inhibitor as fluoxetine $[1,6]$ and it has been suggested that it may play a significant role in the therapeutic effects $[6$, 7]. This is especially relevant because acute, single-administration experimental designs do not achieve significant levels of norfluoxetine until at least after $120 \mathrm{~min}$ have passed.

\section{Human Clinical Ranges}

There are varying reports of both observed and recommended serum concentrations in the clinic. In gen- eral, serum concentrations of combined fluoxetine and norfluoxetine are reported to be between 200 and 1,000 $\mathrm{ng} / \mathrm{ml}[6,9-12]$. However, there is no clear relationship between clinical effect and serum concentration for the SSRIs, including fluoxetine. It has been hypothesized that there may be a curvilinear relationship such as the one described for tricyclic antidepressants [12], although generally dose-response curves appear to be flat [4]. It has also been suggested that instead of a dose-effect curve, there is a threshold that must be exceeded before therapeutic effects emerge [6]. With such a broad range observed clinically and no clear relationship to therapeutic effects, it is difficult to pinpoint optimal serum levels for preclinical studies. Nonetheless, it is important to consider the human clinical conditions.

Our study demonstrates that the pharmacokinetics of fluoxetine are more rapid in nonhuman primates, and that multiple dosing paradigms are best suited for replicating both human serum concentrations and ratios of fluoxetine to norfluoxtine. Specifically, $5.6 \mathrm{mg} / \mathrm{kg}$ administered daily either orally or subcutaneously results in combined serum levels within the reported human clinical range. However, on two occasions sores developed following subcutaneous administration, so when choosing a method for longer studies (i.e. 4-6 weeks) oral administration is probably preferable. In humans, fluoxetine is completely absorbed from the gut but has oral bioavailability less than $90 \%[4,5]$, so to ensure consistent concentrations in the human therapeutic range, we chose a higher dose $(10 \mathrm{mg} / \mathrm{kg} / \mathrm{day})$ for our 6 -week study. This dose, mixed with a variety of palatable foods, reliably produced serum concentrations in the clinical range $(>200$ $\mathrm{ng} / \mathrm{ml}$ ) over the 6 -week period, although concentrations were considerably higher and more variable during the initial two weeks of treatment. These levels (250-450 ng/ $\mathrm{ml}$ ) are comparable to those reported following $20 \mathrm{mg} /$ day and $40 \mathrm{mg} /$ day in humans [6, 9-12].

There are two possible reasons for the reduction in levels seen after week 1 . The first is enzyme induction, which has been reported following fluoxetine administration in rat liver $[17,18]$, and the second is decreasing compliance in consuming the medicated treat, which would be consistent with the experience of Fontenot et al. [13]. There are no studies currently available on the effect of chronic fluoxetine administration on enzymes in the rhesus macaque. While we were not able to quantify compliance, daily visual inspection following treat administration did indicate that levels of compliance varied, suggesting that this is the more probable explanation. Furthermore, given that the concentrations maintained in later weeks of 
chronic treatment are closer to those of the lower doses $(2-4 \mathrm{mg} / \mathrm{kg} /$ day) tested by Fontenot et al. [13], it seems likely that the animals were not consuming the full dose. However, since serum concentrations remained in the clinical range, this is unlikely to pose a problem, especially as the majority of clinical reports are also in this range [9-11].

\section{Conclusions}

This study describes the pharmacokinetics of fluoxetine and its active metabolite norfluoxetine in rhesus macaques. While the half-lives are shorter than those reported in humans, there is still a significant possibility that active concentrations will persist in the blood past the conclusion of treatment, which should be taken into account when designing experiments. As in humans, during chronic administration conditions, norfluoxetine concentrations exceed fluoxetine concentrations. Furthermore, to achieve concentrations comparable to observed human clinical concentrations, multiple, repeated dosing methods are necessary. Daily administration of $10 \mathrm{mg} / \mathrm{kg}$ orally results in consistent concentrations in the clinical range in rhesus macaques, an important consideration when translating results to the human condition.

\section{Acknowledgements}

The authors express their gratitude to Lisa Neidert and Juliet Brown for expert technical assistance, and to Catie Capello, Bailey Glover and the Ritchie lab for assistance with the MS/MS preparation and analyses. This research was supported by DA10344 (L.L.H.), DA000517 (L.L.H.), T-32 DA015040 (E.K.S.), and RR00065 (Yerkes National Primate Research Center).

\section{Disclosure Statement}

The authors declare no conflict of interest.

\section{References}

- Wong DT, Bymaster FP, Engleman EA: Prozac (fluoxetine, Lilly 110140), the first selective serotonin uptake inhibitor and an antidepressant drug: twenty years since its first publication. Life Sci 1995;57:411-441.

-2 Clark RN, Ashby CR Jr, Dewey SL, Ramachandran PV, Strecker RE: Effect of acute and chronic fluoxetine on extracellular dopamine levels in the caudate-putamen and nucleus accumbens of rat. Synapse 1996;23: 125-131.

3 Thompson C: Onset of action of antidepressants: results of different analyses. Hum Psychopharmacol 2002;17(suppl 1):S27-S32.

4 Vaswani M, Linda FK, Ramesh S: Role of selective serotonin reuptake inhibitors in psychiatric disorders: a comprehensive review. Prog Neuropsychopharmacol Biol Psychiatry 2003;27:85-102.

5 Hiemke C, Hartter S: Pharmacokinetics of selective serotonin reuptake inhibitors. Pharmacol Ther 2000;85:11-28.

6 Preskorn SH: Clinically relevant pharmacology of selective serotonin reuptake inhibitors: an overview with emphasis on pharmacokinetics and effects on oxidative drug metabolism. Clin Pharmacokinet 1997;32(suppl $1): 1-21$.
Qu Y, Aluisio L, Lord B, Boggs J, Hoey K, Mazur C, Lovenberg T: Pharmacokinetics and pharmacodynamics of norfluoxetine in rats: increasing extracellular serotonin level in the frontal cortex. Pharmacol Biochem Behavior 2009;92:469-473.

$>8$ Baumann P: Pharmacokinetic-pharmacodynamic relationship of the selective serotonin reuptake inhibitors. Clin Pharmacokinet 1996;31:444-469.

9 Amsterdam JD, Hornig-Rohan JF, Rosenbaum JF, Quitkin FM, Fawcette J, Reimherr FW, Beasley CM Jr: Fluoxetine and norfluoxetine plasma levels in major depression. Biological Psychiatry 1995;37:606.

-10 Baumann P, Hiemke C, Ulrich S, Eckermann G, Gaertner I, Gerlach M, Kuss HJ, Laux G, Muller-Oerlinghausen B, Rao ML, Riederer P, Zernig G: The agnp-tdm expert group consensus guidelines: therapeutic drug monitoring in psychiatry. Pharmacopsychiatry 2004;37:243-265.

11 Brunswick DJ, Amsterdam JD, Fawcett J, Quitkin FM, Reimherr FW, Rosenbaum JF, Beasley CM Jr: Fluoxetine and norfluoxetine plasma concentrations during relapse-prevention treatment. J Affect Disord 2002;68: 243-249.

-12 Reis M, Aamo T, Spigset O, Ahlner J: Serum concentrations of antidepressant drugs in a naturalistic setting: compilation based on a large therapeutic drug monitoring database. Ther Drug Monit 2009;31:42-56.
13 Fontenot MB, Musso MW, McFatter RM, Anderson GM: Dose-finding study of fluoxetine and venlafaxine for the treatment of self-injurious and stereotypic behavior in rhesus macaques (Macaca mulatta). J Am Assoc Lab Anim Sci 2009;48:176-184.

14 Ritchie J, Glover B, Ramsey C, Scott-Harrell $\mathrm{P}$ : A routine uplc-lc/ms/ms assay for the newer antidepressants. Ther Drug Monit 2009; 31:646.

15 Altamura AC, Moro AR, Percudani M: Clinical pharmacokinetics of fluoxetine. Clin Pharmacokinet 1994;26:201-214.

$\checkmark 16$ Hodes GE, Hill-Smith TE, Suckow RF, Cooper TB, Lucki I: Sex-specific effects of chronic fluoxetine treatment on neuroplasticity and pharmacokinetics in mice. J Pharmacol Exp Ther 2010;332:266-273.

17 Haduch A, Wojcikowski J, Daniel WA: Effect of selected antidepressant drugs on cytochrome p450 2b (cyp2b) in rat liver: an in vitro and in vivo study. Pharmacol Rep 2008; 60:957-965

18 Daniel WA, Haduch A, Syrek M, Boksa J: Direct and indirect interactions between antidepressant drugs and cyp2c6 in the rat liver during long-term treatment. Eur Neuropsychopharmacol 2006;16:580-587. 